\title{
The Experiential Strategy to Behavior Change for New Services: Case Study of Uber in Taiwan
}

\author{
Shun-Nung Huang1, Wei-Tien Hung'2, Chia-Han Yang1 \\ ${ }^{1}$ Institute of Creative Industries Design, National Cheng Kung University, Taiwan \\ ${ }^{2}$ Department of Recreation Management, Shih-Chien University, Taiwan \\ Email: sunohuang@gmail.com
}

How to cite this paper: Huang, S.-N., Hung, W.-T., \& Yang, C.-H. (2021). The Experiential Strategy to Behavior Change for New Services: Case Study of Uber in Taiwan. Journal of Service Science and Management, 14, 325-342.

https://doi.org/10.4236/jssm.2021.143020

Received: May 4, 2021

Accepted: June 8, 2021

Published: June 11, 2021

Copyright $\odot 2021$ by author(s) and Scientific Research Publishing Inc. This work is licensed under the Creative Commons Attribution International License (CC BY 4.0).

http://creativecommons.org/licenses/by/4.0/

\begin{abstract}
While the notion of service science was introduced into the world, new services were continually developed to instead of old ones. This could stimulate economy growth again, and improve our life quality, if the new service could be adopted and engage and keep users into service systems. This involves an issue of behavior change. This study proposed an experiential strategy to change behaviors of users. In order to ensure the effectiveness of the experiential strategy, and to exploring how the antecedences of behaviors change under the experiential strategy, a research model in this study was built on the basis of TPB (theory of planed behavior) and stages of readiness for change model (transtheoretial model). This study took Uber as a case to conduct a survey research, and try to identify groups of users by their use experience to collect data. The datasets were analyzed by PLS (Partial Least Square) software. The results supported the effectiveness of the experiential strategy to change behaviors. Through comparing estimated models for groups, this study found that attitude to a service equally influences users' behavioral intention across models. The influence of subjective norm to a new service would decreases, when users' behaviors were more solid. The reverse direction would occur to the behavior control. Conclusions and managerial implications would be also provided on the basis of results of this study.
\end{abstract}

\section{Keywords}

Experiential Strategy, Behavior Change, TPB, Transtheoretial Model

\section{Introduction}

As we enter an age of service science, so many new services were developed recently. In the field of service science, scholars used the service dominant logic 
(SDL) to conceptualize a service, which considered that a service should be viewed as a process utilizing the resources embraced in a service system. According to Maglio \& Spohrer (2008) and Hollebeek et al. (2019), a service system means a value co-production configuration which was composed of people, technology, other service systems, and shared information. Especially, the people in a service system not only mean the operators in a service process, but also the service users. Hence, the users no longer just receive service, they also involve and influence all the aspects of a service.

On the other side, the sustainability of a new service is also an issue (Franca et al., 2017; Tukker, 2004). Number of users always plays a key factor to the new service success. The main reasons are 1) economics of scale; and 2) incomplete service system. When a firm achieves the economics of scale, the average cost of per unit of service is lower than a service which was produced by a firm does not achieve the economics of scale. Under the situation, the firm is more likely to be profitable to keep a firm continue to work. On the other side, the service users would be embraced into a service system to create a new service. This means that the service users play a critical role for a successful new service. In sum, the uses' involvement is a necessary element of a new service.

However, most of providers of new services may face the problem of how promote potential users to adopt new service. If the service users do not adopt new service, it leads to an incomplete service system and inefficiency of operations. Actually, it is an issue naturally involved to behavioral change (OinasKukkonen, 2013). How to change behaviors has been widely discuss in health care (Rollnick et al., 2008), but it is still lack of related research in service science (Hung \& Yuan, 2014). In the health care area, the problem which scholars would confront is that people would addict to some bad behaviors, and could not return to healthy life style. Such unhealthy behaviors may be smoking, drinking, or other bad life style. The similar situation also appears to change behaviors to involve a service system.

Many successful and failure cases were observed in the real world. The successful cases were worth to explore to gain knowledge about changing behavior to a service system. In Taiwan, Uber was an extremely successful case of introducing new service system. This research took the Uber as an example to explore a strategy to change behavior, and to understand the behavioral change process, so that we could propose some suggestions to service promoters to behavioral change.

The contributions of this paper would include: 1) Provide a direction for improvement to new service providers and stabilize the behavior of service users; 2) Assist in improving the marketing strategies of service providers to build a more stable business model; 3) Discover the future development of the sharing economy Trends for new service businesses to learn from and create value; 4) To further understand the possible ways to intervene in user behavior changes.

However, the research limitations of this article: 1) funding and time con- 
straints, the results of this research are not long-term observations; 2) collecting responses through web pages, excluding TV and paper questionnaires, the approch could be more limited; 3 ) sample of the elderly If the number is small, it may not be able to accurately reflect the demographic characteristics; 4) Different cultures and life backgrounds may show differences in the results of intervention.

The purpose of the study is to build a model describing how behaviors change and develop a strategy to push the progress of behavior change. This study used TPB (theory of planed behavior) and stages of readiness for change model (transtheoretial model) to build the research model.

Due to this purpose, this article is organized as follows: In Section 2, in order to building the research model, the theoretical foundation and proposed strategy for behavior change were detailed in this section; In Section 3, would describe the methodology in this study; In Section 4, would report the result of statistical analysis; And some implications were proposed in Section 5.

\section{Literature Review}

\subsection{Transtheoretical Model}

This study aims to explore how behaviors change, and to propose strategy to behaviors change. First of all, the research needs a theoretical foundation to present the process of behavior change. Prochaska et al. (1992) proposed a model, the stages of readiness for change model, which framed behavioral change process as five stages model. These stages were pre-contemplation, contemplation, preparation, action, and maintenance. The descriptions for these stages were integrated in Table 1. The model has been used in medical field (Prochaska \& Velicer, 1997; Tseng et al., 2017), and researches related to agricultural (Lemken et al., 2017), financial management (Boonroungrut \& Fei, 2020; Delgadillo, 2017), adolescent academic performance (Moreira et al., 2020), forest legacy planning (Quartuch et al., 2021), consumer behavior (Davoodi et al., 2018; Gur et al., 2019), travel behavior (Friman et al., 2017), counseling (Stewart-Sicking et al., 2017), and exercises (Abula et al., 2018; Marcus \& Simkin, 1994).

Table 1. The descriptions for five stages in a process of behavioral change.

\begin{tabular}{|c|c|c|c|}
\hline No. & $\begin{array}{l}\text { Stage of behavior } \\
\text { change }\end{array}$ & Behavioral status & $\begin{array}{l}\text { Psychologica } \\
\text { intensity }\end{array}$ \\
\hline 1 & Pre-Contemplation & No intentions to adopt behaviors in six months & Never \\
\hline 2 & Contemplation & Having intentions to adopt behaviors in six months & Someday \\
\hline 3 & Preparation & The user will take actions in thirty days & Soon \\
\hline 4 & Action & $\begin{array}{c}\text { The user has changed behavior for months which is } \\
\text { shorter than six months }\end{array}$ & Now \\
\hline 5 & Maintenance & $\begin{array}{l}\text { The user has changed behavior for months which is } \\
\text { greater than six months }\end{array}$ & Forever \\
\hline
\end{tabular}

Source: Prochaska et al., 1992. 


\subsection{Theory of Planned Behavior}

In the area of behavior research, the most widely adopted theories are theory of reasoned action (TRA) and theory of planned behavior (TPB). Especially the theory of planned behavior may be a good start point for this research. It provided us important antecedents of a behavior intention, so that we could observe the change of behavioral antecedents through the stages of behavioral change process (transtheoretial model).

TPB was developed by the revision on TRA. TRA was proposed by Fishbein \& Ajzen (1975), which argued that human behaviors were resulted from a behavior intention (Karnowski et al., 2018; Lin \& Wang, 2020). Furthermore, attitude, and subjective norms to a specific behavior determine the intention to a specific behavior. Years later, TRA was revised to propose TPB (Theory of Planned Behavior) (Ajzen, 1991). The revision on TRA was derived from an assumption of TRA, which assume people have full ability to control their behaviors. Obviously, the assumption could not be recognized by most scholars. For example, elderly people cannot use computer to reserve tickets online because of the technical obstacle, even they have intention to do this. Hence, Ajzen (1991) added a variable, behavior control, into TRA to rename the model as TPB. In other words, TPB recognized that one's ability of behavior control also influence behavior intention, and then actual behaviors. In sum, TBP argued that a behavior intention was influenced by attitude, subjective norms, and behavior control (Buckley et al., 2018; Gao et al., 2017).

Through numerous studies, TRA and TPB were verified to confirm its ability to explain the human behaviors. Both two theoretical models were good to help us to understand how a behavior is formatted, however it just provided a limited implication to normative aspect to tell us how we could help service promoter gradually change users' behavior in a new service context. Due to the reason, this study combined the stages of readiness for change model and TPB to analyze how the factors in TPB change to push the progress of behavioral change in the five-stage model. The conceptual model was presented as blow.

Ideally, the users' behaviors should be push forward along the five-stage model being more and more solid. For example, in Taiwan, the government have promote using electronic invoice for a long time in order to reduce resource wastes and to protect environment, but the action was almost to get failure. On a basis of Figure 1, we could expect that the readiness of behaviors was push forward due to the antecedents of behaviors in TPB change. Conversely, we could investigate how is the status of these antecedents for a behavior intention at each stage, which will be helpful to understand how to influence these antecedents to push behavior change progress along the five-stage model.

\subsection{Experiential Intervention and Research Framework}

As the earlier description for importance of strategies to behavioral changes, scholars were delegated to look for a way to change behaviors. Here this research 


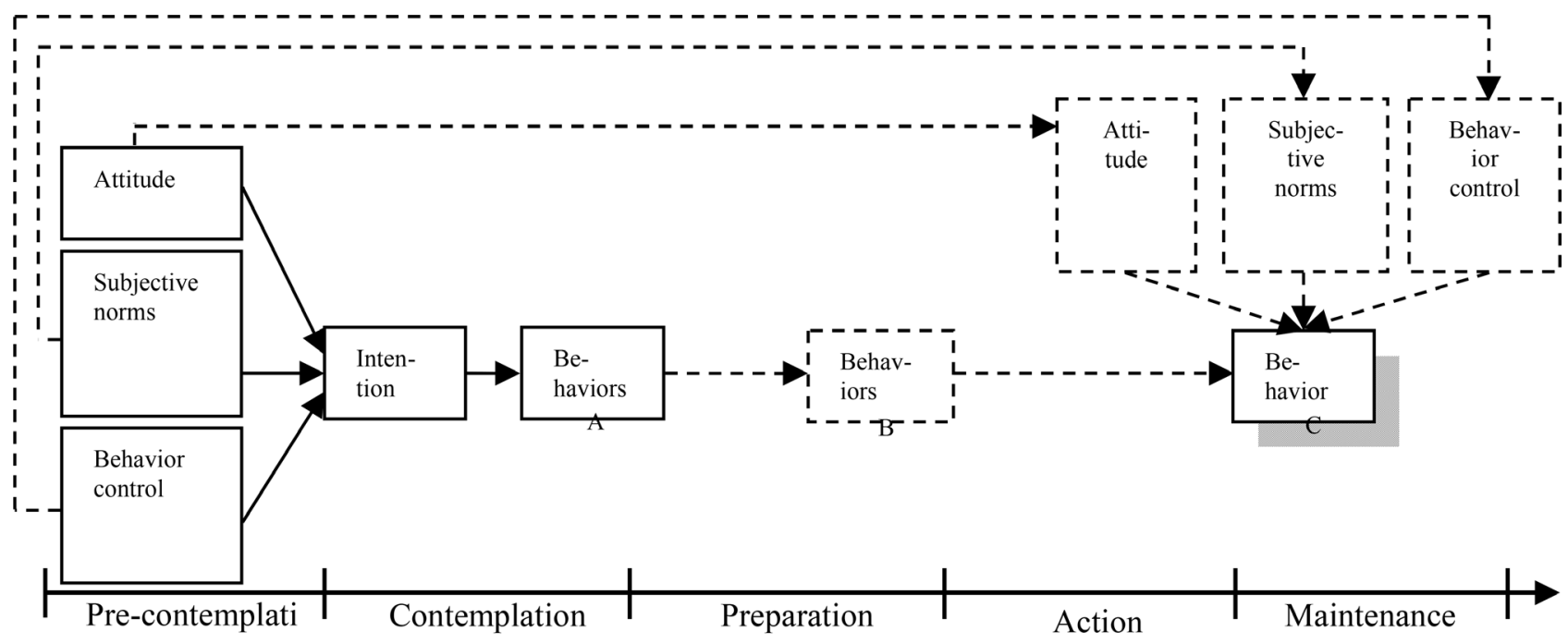
on

Figure 1. An integrated framework of TPB and transtheoretial model.

proposed an experiential strategy to change behaviors through providing continuous experiences to potential users to enhance their readiness to new things such as new services or a life style.

Recent years the term, experience, appeared in many fields with different and indefinite definition. In service management field, the concept of experience was always used to being an element of a business model. Pine \& Gillmore (1998) first proposed the idea of experience economy which reminds us that our economy system is going under a progress which starts from commodities to experience through products and services. Prahalad \& Ramaswamy (2004) also proposed the experience-centric view which argued that competition focus would shift to experiences from products or services. Voss et al. (2008) further proposed a term of experience-centric service on a basis of Prahalad \& Ramaswamy's (2004) perspective. The experience-centric service emphasized the experience is the core of service provided by companies. As these view points, scholars considered that experience is the source of customer value.

On the other side, the role of experience changed recent years. The critical point was customer-dominant logic (CDL) (Heinonen \& Strandvik, 2015). In terms of CDL, experiences normally involved subjective feeling of customers or users. In a service system, someone's experience may be totally different from others, which was determined by how the users involve the service system. Heinonen \& Strandvik (2015) said that "adopting this view means shifting the focus from how (systems of) providers involve customers in their processes to how customers in their ecosystems engage different types of providers. In other words, emphasizing how customers embed service in their processes rather than how firms provide service to customers (Carlson et al., 2019a; Carlson et al., 2019b)." According to Heinonen et al. (2010), the CDL emphasized the customer's activities, experience and the role of providers in the context constructed form customer perspective. 
To be different from view of service management, this study advanced CDL to first use the concept of experience to be a behavior change strategy. The theoretical foundation of the experiential strategy is based on the experience-based learning (Andresen et al., 2000). Andresen et al. (2000) considered that the experience is the foundation of, and stimulus for learning. This is the one of assumptions to experience-based learning, which supported the idea of this study that the antecedents of behavior intention were stimulated to change, and then to concrete users' behaviors. The connection between experience-based learning and CDL is that how users involve a service system would influence what the experience they construct, and then the results of behavior change.

In sum, this study argued that experience is not only a source of value, but also to be a strategy to change behaviors. In facts, resent years taking experiences as educational strategies was paid attentions especially in primary education, cultural arts, leisure education et al. On a basis of literature, taking experiential interventions as a strategy to change users' behaviors to be a part of service system may be supported. Therefore this study aims to exploring how experiential interventions improve readiness of a behavior along the stages of readiness for change model through altering the antecedents in TBP. The research framework of this study was showed as Figure 2.

\section{Methodology}

\subsection{Research Design and questionnaire Development}

To test if the experiential interventions are effective to improve behavioral readiness, this study designed multi-tiers questionnaire which was presented to responses through web page. The aim of this questionnaire design was discriminating responses into five stages according to their readiness to adopt Uber's service, and measuring the factors proposed by TPB.

The first-tier questionnaire included three questions which were "Do you

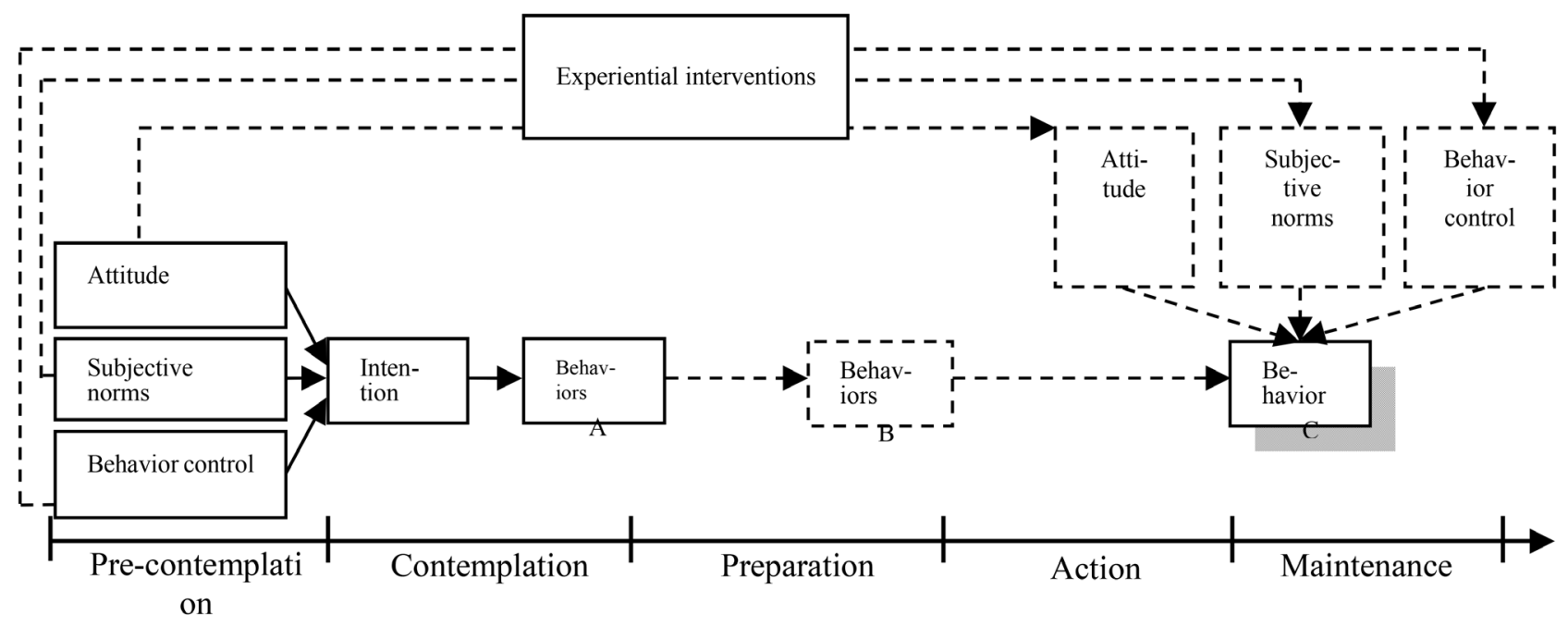

Figure 2. The hypothetical role of experiential interventions in behavioral changes. 
know Uber and its service?" "Have you used taxi service in near six months?" and "How long have you known Uber and its service?" Anyone who choice "No" in first or second questions would exclude to my dataset analyzed later, because these responses did not adopt Uber due to that they do not have demand on taxi service, or know the Uber's service, but not due to the rigidity of their behaviors.

While the response goes through first-tier questionnaire, the second-tier questionnaire would show a question which was "So far how many times you have used Uber?" This is a multiple choice question. Its choices include (1) Never (2) 1 time (3) 2 - 5 times (4) 6 - 10 times (5) above 10 times. The questionnaire system would lead responses who choice (1) to fulfill questions designed for measuring factors in TPB and personal information to finish the test. Other responses who choice (2), (3), (4) or (5) would be lead to go through other questions which aims to measuring their readiness to Uber's service, measuring factors proposed by TPB, and personal information.

All measurement items were design based on a 7-point Likert scale. Through the web-based questionnaire design, the author could have a sample which was structured as Table 2 shown.

\subsection{Pretest for Measurements}

The measurement items of this study were adopted from Ajzen (2002) who was the founder of TPB. Even these items were recognized and used by scholars in the world, measurement biases may occur when we used measurement items in a different social context. Therefore, a pretest for the measurement items which were used in large-scale survey was conducted before the large-scale survey was conducted. The pretest was for the items which were used to measure latent variables, which covered the variables in TPB.

Five items were designed to measure user's attitude for a service, and subjective norm, and behavioral control for a service were measured by two items. In this study, two sets of measurement items for behavior intention were designed for users put in different groups. The users in group 1 were responders who know what Uber is but have not used Uber yet, and the users in group 2 or group 3 were responsers who have used Uber one time or above. All items were verified by CFA (Confirmatory Factor Analysis). The result of pretest showed that each items located at the appropriate construct and were with a factor loading which is greater than 0.8 , which means that items could validly measure focal latent variables. According to value of Cronbach's alpha for each construct, each

Table 2. The structure of sample collected.

\begin{tabular}{cccc}
\hline Group & No.1 & No.2 & No.3 \\
\hline Times to use Uber & Never & 1 time & Above 2 times \\
Score for each factors proposed by TPB & Yes & Yes & Yes \\
Readiness of their behavior & ---- & Yes & Yes \\
Personal information & Yes & Yes & Yes \\
\hline
\end{tabular}


the values were greater than 0.9 , which means the scales used in this study were highly reliable. Hence, the scales used in this study were determined as with validity and reliability to conducting a large-scale survey. The result of pretest was summarized in Table 3.

\subsection{Sampling Procedure}

After the pretest was complete to ensure validity and reliability of scales, the author hired an online survey company to create a web-based questionnaire, and conduct a large-scale survey. The sampling procedure was required to be random. And the sample size calculation was determined by using the formula of Cochran (1977) as

$$
n=\frac{Z^{2} P Q}{d^{2}}
$$

where, $n$ is the sample size; $Z$ is the selected critical value of desired confidence level (1.96); $P$ is the (estimated) proportion of the population which has the attribute in question (0.05); $Q$ is $1-P(0.05) ; d$ is the desired level of precision (0.05). Thus $n=\left(1.96^{2} \star 0.05 * 0.05 / 0.05^{2}\right)=384.16=384$. The author required more than 50 responses from people who know Uber but never use its service, more than 50 responses from people who only use Uber by one time, and to collect more than 50 responses from each stages of readiness model (five-stage model). Totally, 460 responses were collected to analysis. 144 responses were collected from population who know Uber but never use its service. 97 responses

Table 3. Pretest.

\begin{tabular}{|c|c|c|c|c|c|}
\hline Variables & Items & Means & S.D. & $\begin{array}{c}\text { Factor } \\
\text { loading }\end{array}$ & $\begin{array}{l}\text { Cronbach's } \\
\text { alpha }\end{array}$ \\
\hline \multirow{5}{*}{ Attitude } & \multirow{5}{*}{5} & 4.9483 & 1.38187 & 0.813 & \multirow{5}{*}{0.96} \\
\hline & & 4.8103 & 1.22054 & 0.860 & \\
\hline & & 4.8793 & 1.17096 & 0.858 & \\
\hline & & 5.1897 & 1.09955 & 0.916 & \\
\hline & & 5.0345 & 1.16928 & 0.907 & \\
\hline \multirow{2}{*}{ Subjective norm } & \multirow{2}{*}{2} & 4.6897 & 1.27330 & 0.922 & \multirow{2}{*}{0.914} \\
\hline & & 4.8448 & 1.19651 & 0.922 & \\
\hline \multirow{2}{*}{ Behavioral control } & \multirow{2}{*}{2} & 5.3448 & 1.39613 & 0.914 & \multirow{2}{*}{0.904} \\
\hline & & 5.3448 & 1.29170 & 0.914 & \\
\hline \multirow{3}{*}{$\begin{array}{c}\text { Intention } \\
\text { (for group 1) }\end{array}$} & \multirow{3}{*}{3} & 4.4655 & 1.02966 & 0.926 & \multirow{3}{*}{0.95} \\
\hline & & 4.5000 & 1.12780 & 0.898 & \\
\hline & & 4.2069 & 1.10436 & 0.910 & \\
\hline \multirow{2}{*}{$\begin{array}{c}\text { Intention } \\
\text { (for group } 2 \& 3 \text { ) }\end{array}$} & \multirow{2}{*}{2} & 5.4483 & 1.02892 & 0.959 & \multirow{2}{*}{0.955} \\
\hline & & 5.2931 & 1.13945 & 0.959 & \\
\hline
\end{tabular}


were collected from population who only use Uber by one time. Other responses were collected from population who use Uber beyond 2 times. In terms of stages of readiness, each stage has more than 50 responses who were collected from population.

\subsection{Analytical Tools}

The dataset collected was analyzed by SPSS and Lohmoller's (1981) partial least-squares (PLS) algorithm. SPSS software helped the author to do descriptive statistics knowing the trend between use experience and stages of readiness. While the trend was observed, the next was estimating the structure models for each group. In order to estimating the TPB model in each stages, PLS is an appropriate technique for this study. PLS is a tool for estimating model of latent constructs based on linear combinations of their empirical indicators and the structural model for constructs in the research model. PLS has flexible assumptions to the sample's distribution, it allow us just require a smaller sample to estimate the model. In other words, PLS is especially used to the research which has a small sample (Chin \& Newsted, 1999). This is a crucial advantage of PLS when the research only has a relatively small sample.

\section{Results}

\subsection{Descriptive Statistics}

According to the experience-based learning theory (Andresen et al., 2000), experience is the antecedence of behavior, so that a cross table could be used to observe how the experience influences a user located in a stage of readiness. Table 4 is the contingency table which obviously showed that users were pushed to next stage of readiness along increasing use experience of Uber. The data showed that the use experiences of a service may change users' behavior in terms of their

Table 4. The distribution of samples along stages of readiness model.

\begin{tabular}{ccccccc}
\hline & $\mathbf{0}$ & $\mathbf{1}$ & $\mathbf{2}-\mathbf{5}$ & $\mathbf{6 - 1 0}$ & Above 10 & Total \\
\hline Pre-contemplation & 75 & 22 & 9 & 0 & 0 & 106 \\
$\%$ & $(70.8 \%)$ & $(20.8 \%)$ & $(8.4 \%)$ & $(0 \%)$ & $(0 \%)$ & $(100 \%)$ \\
Contemplation & 67 & 31 & 44 & 7 & 4 & 153 \\
$\%$ & $(43.8 \%)$ & $(20.3 \%)$ & $(28.8 \%)$ & $(4.5 \%)$ & $(2.6 \%)$ & $(100 \%)$ \\
Preparation & 2 & 9 & 26 & 19 & 11 & 67 \\
$\%$ & $(3 \%)$ & $(13.4 \%)$ & $(38.8 \%)$ & $(28.4 \%)$ & $(16.4 \%)$ & $(100 \%)$ \\
Action & 0 & 29 & 34 & 8 & 1 & 72 \\
$\%$ & $(0 \%)$ & $(40.3 \%)$ & $(47.2 \%)$ & $(11.1 \%)$ & $(1.4 \%)$ & $(100 \%)$ \\
Maintenance & 0 & 6 & 22 & 10 & 24 & 62 \\
$\%$ & $(0 \%)$ & $(9.7 \%)$ & $(35.5 \%)$ & $(16.1 \%)$ & $(38.7 \%)$ & $(100 \%)$ \\
Total & 144 & 97 & 135 & 44 & 40 & 460 \\
\hline
\end{tabular}


readiness to a new service.

After confirming the effect of use frequency to readiness to Uber's service, the next step in this study was to explore how the factors in TPB influence the frequency of use, and then the readiness to a new service in terms of a psychology perspective.

\subsection{Validity and Reliability of Measurement Models}

In order to estimate the structure models for three groups, the validity and reliability of measurements should be confirmed as well as requirements for doing PSL analysis. In PLS analysis, convergent validity and discriminant validity were criteria to estimate the validity of a measurement. To fulfill the requirement of convergent validity, the factor loading of each item should be greater than 0.6 , and the t-value for each item should be statistically significant at $P=0.001$ level (Anderson \& Gerbing, 1988). That average variance extracted (AVE) should be greater than 0.5 were one of criteria for convergent validity. Tables 5-7 showed that all the measurements for estimating each model for three groups were qualified in terms of convergent validity.

The convergent validity verified how items could measure the correspondent construct validly, but the discriminant validity verified how the constructs is separated to other constructs. The criterion for discriminant validity is that the roof of average variance extracted of each construct should be greater than the correlation between the construct and other constructs (Fornell \& Larcker, 1981). Tables 8-10 showed that each measurement models for each groups fulfilled the criterion to establish discriminant validities.

In addition to validity, a qualified measurement model also needs to fulfill the criterion for composite reliability. In PLS analysis, the composite reliability of

Table 5. Validity and reliability of measurement models (Group 1).

\begin{tabular}{|c|c|c|c|c|c|c|}
\hline No. & Variables & Items & $\begin{array}{l}\text { Factor } \\
\text { loading }\end{array}$ & t-value & $\begin{array}{l}\text { Composite } \\
\text { reliability }\end{array}$ & $\begin{array}{c}\text { Average variance } \\
\text { extracted }\end{array}$ \\
\hline \multirow{5}{*}{1} & \multirow{5}{*}{ Attitude } & A1 & 0.834 & 21.437 & \multirow{5}{*}{0.918} & \multirow{5}{*}{0.692} \\
\hline & & A2 & 0.742 & 11.529 & & \\
\hline & & A3 & 0.801 & 8.510 & & \\
\hline & & A4 & 0.884 & 32.126 & & \\
\hline & & A5 & 0.889 & 32.829 & & \\
\hline \multirow{2}{*}{2} & \multirow{2}{*}{$\begin{array}{c}\text { Subjective } \\
\text { norm }\end{array}$} & CR1 & 0.959 & 80.714 & \multirow{2}{*}{0.952} & \multirow{2}{*}{0.909} \\
\hline & & CR2 & 0.948 & 41.743 & & \\
\hline \multirow{2}{*}{3} & \multirow{2}{*}{$\begin{array}{c}\text { Behavioral } \\
\text { control }\end{array}$} & $\mathrm{BC} 1$ & 0.953 & 87.240 & \multirow{2}{*}{0.948} & \multirow{2}{*}{0.900} \\
\hline & & $\mathrm{BC} 2$ & 0.945 & 44.356 & & \\
\hline \multirow{3}{*}{4} & \multirow{3}{*}{$\begin{array}{l}\text { Behavior } \\
\text { intention }\end{array}$} & B1 & 0.955 & 64.310 & \multirow{3}{*}{0.963} & \multirow{3}{*}{0.896} \\
\hline & & B2 & 0.950 & 76.003 & & \\
\hline & & B3 & 0.934 & 48.227 & & \\
\hline
\end{tabular}


Table 6. Validity and reliability of measurement models (Group 2).

\begin{tabular}{|c|c|c|c|c|c|c|}
\hline No. & Variables & Items & $\begin{array}{l}\text { Factor } \\
\text { loading }\end{array}$ & $t$-value & $\begin{array}{l}\text { Composite } \\
\text { reliability }\end{array}$ & $\begin{array}{l}\text { Average variance } \\
\text { extracted }\end{array}$ \\
\hline \multirow{5}{*}{1} & \multirow{5}{*}{ Attitude } & $\mathrm{A} 1$ & 0.742 & 9.227 & \multirow{5}{*}{0.941} & \multirow{5}{*}{0.761} \\
\hline & & A2 & 0.884 & 18.588 & & \\
\hline & & A3 & 0.906 & 30.277 & & \\
\hline & & $\mathrm{A} 4$ & 0.905 & 32.378 & & \\
\hline & & A5 & 0.914 & 33.945 & & \\
\hline \multirow{2}{*}{2} & \multirow{2}{*}{$\begin{array}{l}\text { Subjective } \\
\text { norm }\end{array}$} & CR1 & 0.940 & 35.635 & \multirow{2}{*}{0.943} & \multirow{2}{*}{0.982} \\
\hline & & CR2 & 0.949 & 59.252 & & \\
\hline \multirow{2}{*}{3} & \multirow{2}{*}{$\begin{array}{c}\text { Behavioral } \\
\text { control }\end{array}$} & $\mathrm{BC} 1$ & 0.944 & 45.981 & \multirow{2}{*}{0.941} & \multirow{2}{*}{0.888} \\
\hline & & BC2 & 0.941 & 41.587 & & \\
\hline \multirow{2}{*}{4} & Behavior & $\mathrm{B} 1$ & 0.959 & 55.265 & \multirow{2}{*}{0.960} & \multirow{2}{*}{0.924} \\
\hline & intention & B2 & 0.963 & 59.600 & & \\
\hline
\end{tabular}

Table 7. Validity and reliability of measurement models (Group 3).

\begin{tabular}{|c|c|c|c|c|c|c|}
\hline No. & Variables & Items & $\begin{array}{l}\text { Factor } \\
\text { loading }\end{array}$ & t-value & $\begin{array}{c}\text { Composite } \\
\text { reliability }\end{array}$ & $\begin{array}{c}\text { Average variance } \\
\text { extracted }\end{array}$ \\
\hline \multirow{5}{*}{1} & \multirow{5}{*}{ Attitude } & $\mathrm{A} 1$ & 0.676 & 7.999 & \multirow{5}{*}{0.939} & \multirow{5}{*}{0.758} \\
\hline & & A2 & 0.919 & 65.117 & & \\
\hline & & $\mathrm{A} 3$ & 0.907 & 60.719 & & \\
\hline & & A4 & 0.916 & 57.310 & & \\
\hline & & A5 & 0.909 & 21.0259 & & \\
\hline \multirow{2}{*}{2} & \multirow{2}{*}{$\begin{array}{l}\text { Subjective } \\
\text { norm }\end{array}$} & CR1 & 0.976 & 202.265 & \multirow{2}{*}{0.976} & \multirow{2}{*}{0.954} \\
\hline & & CR2 & 0.978 & 238.918 & & \\
\hline \multirow{2}{*}{3} & \multirow{2}{*}{$\begin{array}{c}\text { Behavioral } \\
\text { control }\end{array}$} & $\mathrm{BC} 1$ & 0.961 & 149.207 & \multirow{2}{*}{0.961} & \multirow{2}{*}{0.925} \\
\hline & & BC2 & 0.963 & 171.055 & & \\
\hline \multirow{2}{*}{4} & Behavior & B1 & 0.975 & 184.878 & \multirow{2}{*}{0.975} & \multirow{2}{*}{0.951} \\
\hline & intention & B2 & 0.975 & 167.076 & & \\
\hline
\end{tabular}

Table 8. Comparisons between correlations and roots of AVE of each variable (group 1).

\begin{tabular}{ccccccc}
\hline Variables & Mean & S.D. & Attitude & $\begin{array}{c}\text { Subjective } \\
\text { norm }\end{array}$ & $\begin{array}{c}\text { Behavioral } \\
\text { control }\end{array}$ & $\begin{array}{c}\text { Behavior } \\
\text { intention }\end{array}$ \\
\hline Attitude & 4.1944 & 0.8177 & 0.832 & & & \\
Subjective norm & 4.0659 & 0.8173 & 0.633 & 0.953 & & \\
Behavioral control & 4.6458 & 1.2957 & 0.413 & 0.349 & 0.949 & \\
Behavior intention & 4.2708 & 1.1850 & 0.708 & 0.685 & 0.487 & 0.946 \\
\hline
\end{tabular}

each constructs was required to be more than 0.75 . According to the information in Tables 5-7, all the measurement models were qualified in terms of the criterion for composite reliability. 
Table 9. Comparisons between correlations and roots of AVE of each variable (group 2).

\begin{tabular}{ccccccc}
\hline Variables & Mean & S.D. & Attitude & $\begin{array}{c}\text { Subjective } \\
\text { norm }\end{array}$ & $\begin{array}{c}\text { Behavioral } \\
\text { control }\end{array}$ & $\begin{array}{c}\text { Behavior } \\
\text { intention }\end{array}$ \\
\hline Attitude & 4.6659 & 1.0443 & 0.873 & & & \\
Subjective norm & 4.2989 & 1.0546 & 0.799 & 0.961 & & \\
Behavioral control & 5.0876 & 1.1729 & 0.722 & 0.752 & 0.945 & \\
Behavior intention & 4.7731 & 1.1381 & 0.577 & 0.607 & 0.408 & 0.942 \\
\hline
\end{tabular}

Table 10. Comparisons between correlations and roots of AVE of each variable (group 3).

\begin{tabular}{ccccccc}
\hline Variables & Mean & S.D. & Attitude & $\begin{array}{c}\text { Subjective } \\
\text { norm }\end{array}$ & $\begin{array}{c}\text { Behavioral } \\
\text { control }\end{array}$ & $\begin{array}{c}\text { Behavior } \\
\text { intention }\end{array}$ \\
\hline Attitude & 5.2772 & 1.1019 & 0.871 & & & \\
Subjective norm & 5.0272 & 1.1823 & 0.796 & 0.962 & & \\
Behavioral control & 5.5681 & 1.0862 & 0.818 & 0.858 & 0.975 & \\
Behavior intention & 5.5022 & 1.1374 & 0.754 & 0.709 & 0.719 & 0.977 \\
\hline
\end{tabular}

\subsection{Structural Models}

After the measurement models were verified by criteria to reliability and validity, we could start to estimate structural models. In this study, there were three models which were estimated and compared to each other to see if the experiential intervention is effective to change behaviors. Furthermore, through comparing three models we also could see how the experiential intervention changes the antecedents of behavioral intention. Figure 3 showed the estimated structure model for group 1 which contained the respondents who have never used Uber's service, but know what the Uber is. As Figure 3 showed, the intention to use Uber for people who never used Uber was mainly influenced by attitude ( $\beta=$ $0.395, P<0.001)$, and subjective norm $(\beta=0.367, P<0.001)$. Behavioral control ( $\beta=0.196, P<0.05)$ was a minor factor to behavioral intention. The $\mathrm{R}^{2}$ is equal to 0.626 .

Figure 4 showed the estimated structure model for group 2 which contained the responses who just used Uber's service one time. The intention to use Uber for people who just used Uber was equally influenced by attitude $(\beta=0.401, P<$ $0.01)$, subjective norm $(\beta=0.371, P<0.001)$, and behavioral control $(\beta=0.225$, $P<0.05)$. The $\mathrm{R}^{2}$ is equal to 0.626 .

Compared Figure 4 with Figure 3, we found that the behavior control slightly increased against to the variable in Figure 3, which may be what the effect of experience intervention is. According to Ajzen (1991), the behavioral control is a variable which represent the degree of which someone has ability to perform the behavior. Hence, the experiential intervention may improve user confidence to use a new service.

Figure 5 showed the structural model for group 3 which contained the responses who use Uber's service more than one time. The model showed that the 


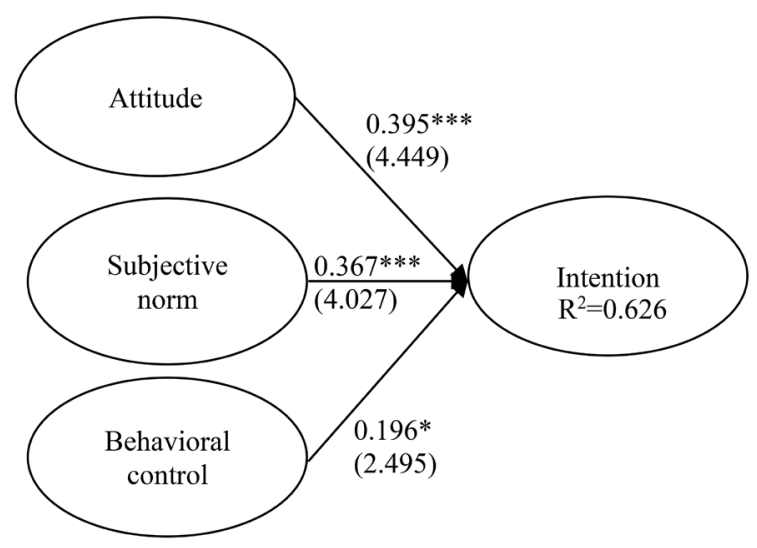

Figure 3. Estimated structure model for group 1.

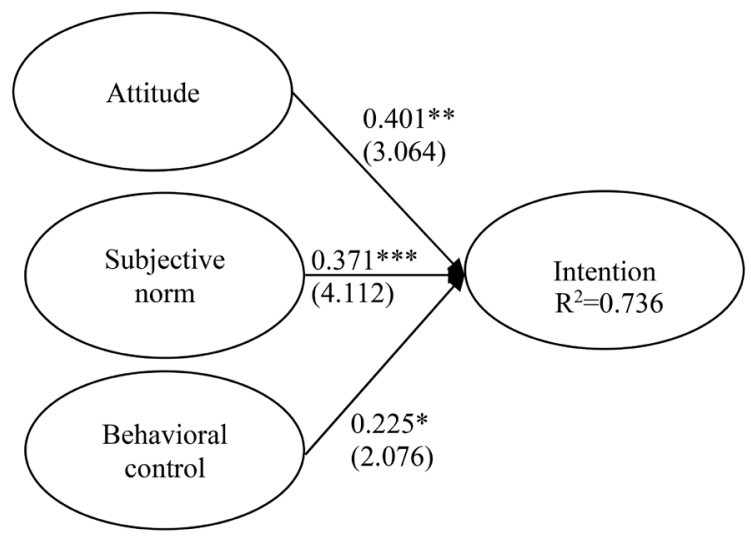

Figure 4. Estimated structure model for group 2.

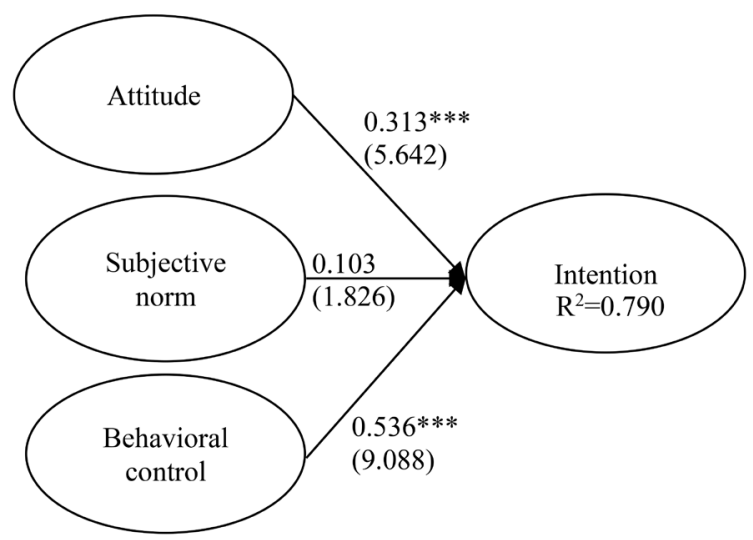

Figure 5. Estimated structure model for group 3.

behavior intention of an experienced user was influenced by attitude $(\beta=0.313$, $P<0.001)$, and behavioral control $(\beta=0.536, P<0.001)$. The model also told us that the subjective norm $(\beta=0.103, \mathrm{t}=1.826)$ is not important to an experienced user's behavior intention.

Compared the Figure 5 with Figure 3, and Figure 4, the author found that the attitude to a new service play an equally significant role to stimulating behavior intention in three models. On the other side, the importance of subjective 
norm would decrease when the users have more and more use experiences to a new service, but behavior control is an important factor to trigger the behavior to continually use a new service.

\section{Discussions}

According to the PLS reports, the antecedents for the behavioral intentions to Uber were changes across models, which also means importance of behavioral antecedents for users located in each stages was difference. The $\beta$ coefficients of each variable across models were summarized and compared in Figure 6.

Obviously, the experience of using Uber would change the antecedences to behavioral intention, and then a user would locate at a specific stage of readiness. As Figure 6 showed, the attitude is equally important across models. This means the judgments on a service is always important to decision to continually use services.

However, the situations were totally different on subjective norm, and behavior control. The data told us that more experiences could reduce the influence of subjective norm on behavioral intention. Opinions coming from other people are especially influential, while an entirely new service was introduced. This finding is especially significant to introducing such new services. The importance of behavior control also radically changed across models. It means that more experiences make users more confidence to use the service, and then trigger the continued use of a service.

\section{Conclusion}

On a basis of result of descriptive statistics, and structure models analysis, this study could provide two remarks which would help new service providers change, and then stabilize users' behavior. First remark is about the experiential intervention for behavior change. This study found that the experiential interventions could push the readiness for a new service forward along the transtheoretial

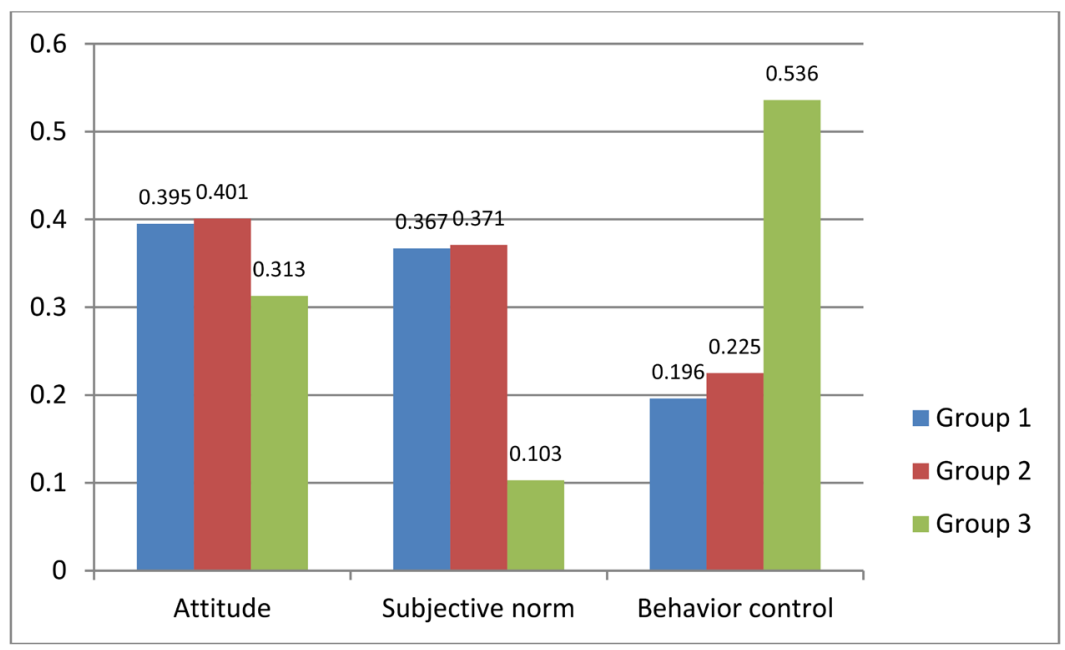

Figure 6. Estimated structure model for group 3. 
model. In other words, more use experience could facilitate behavioral change, and form constant behaviors. The most failures of new service were caused by that potential consumers cannot change or adapt their behaviors to new services, so that service providers could not sustain their business to reach to an economic scale for sustainability.

The first remark suggested that service providers should conduct marketing strategies to enlarge the possibility that potential customers were continually attracted to try and engage to their new service. This would effectively help service providers to form a long-term behavior of customers to using new service. Therefore, the customer base will be fostered to an economic scale gradually.

Furthermore, this study also found that the importance of antecedences in TPB would change to cause the advance of readiness for a new service. No matter how the readiness of a user is, attitude was always equally important to behavior formation. On the other side, the importance of subjective norm would decrease with the advance of readiness of a user, the importance of behavior control would increase with the advance of readiness of a user. The finding suggested that service promoters should design different experiential strategies to the users located at each stage. The purpose of designing the different experiential strategies is to use a specific experiential strategy to enhance the specific factor in TPB in order to push the readiness of the behavior along transtheoretial model.

\section{Acknowledgements}

This article is part of outcome of the research project entitled "Experiences as a strategy for behavioral changes (104-05-06009)" supported by Shih-Chien University (Kaohsiung campus). The author would like to offer thanks to Shih-Chien University (Kaohsiung campus).

\section{Conflicts of Interest}

The authors declare no conflicts of interest regarding the publication of this paper.

\section{References}

Abula, K., Gropel, P., Chen, K., \& Beckmann, J. (2018). Does Knowledge of Physical Activity Recommendations Increase Physical Activity among Chinese College Students? Empirical Investigations Based on the Transtheoretical Model. Journal of Sport and Health Science, 7, 77-82. https://doi.org/10.1016/j.jshs.2016.10.010

Ajzen, I. (1991). The Theory of Planned Behavior. Organizational Behavior and Human Decision Processes, 50, 179-211. https://doi.org/10.1016/0749-5978(91)90020-T

Ajzen, I. (2002) Constructing a TpB Questionnaire: Conceptual and Methodological Considerations.

http://chuang.epage.au.edu.tw/ezfiles/168/1168/attach/20/pta_41176_7688352_57138.p df

Anderson, J. C., \& Gerbing, D. W. (1988). Structural Equation Modeling in Practice-A 
Review and Recommended 2-Step Approach. Psychological Bulletin, 103, 411-423. https://doi.apa.org/doi/10.1037/0033-2909.103.3.411

Andresen, L., Boud, D., \& Cohen, R. (2000). Experience-Based Learning. Understanding Adult Education and Training (2nd ed.). London: Routledge.

Boonroungrut, C., \& Fei, H. (2020). Measurement Validation for Money Management Intention Based on the Transtheoretical Model of Behavior Change. Journal of Behavioral Science, $15,38-53$.

Buckley, L., Kaye, S. A., \& Pradhan, A. K. (2018). Psychosocial Factors Associated with Intended Use of Automated Vehicles: A Simulated Driving Study. Accident Analysis and Prevention, 115, 202-208. https://doi.org/10.1016/j.aap.2018.03.021

Carlson, J., Rahman, M. M., Taylor, A., \& Voola, R. (2019a). Feel the VIBE: Examining Value-in-the-Brand-Page-Experience and Its Impact on Satisfaction and Customer Engagement Behaviours in Mobile Social Media. Journal of Retailing and Consumer Services, 46, 149-162. https://doi.org/10.1016/j.jretconser.2017.10.002

Carlson, J., Wyllie, J., Rahman, M. M., \& Voola, R. (2019b). Enhancing Brand Relationship Performance through Customer Participation and Value Creation in Social Media Brand Communities. Journal of Retailing and Consumer Services, 50, 333-341. https://doi.org/10.1016/j.jretconser.2018.07.008

Chin, W. W., \& Newsted, P. R. (1999). Structural Equation Modeling Analysis with Small Samples Using Partial Least Squares. In R. H. Hoyle (Ed.), Statistical Strategies for Small Sample Research (1st ed., pp. 307-341). Thousand Oaks, CA: SAGE Publications, Inc.

Cochran, G. W. (1977). Sampling Techniques (3rd ed.). New York, NY: John Wiley and Sons.

Davoodi, S. H., Agah, B., Aghamolaei, T., Ghanbarnejad, A., Dadipoor, S., \& Moradabadi, A. S. (2018). Fish Consumption Based on Transtheoretical Model among Housewives. Journal of Education and Health Promotion, 7, Article No. 25. https://doi.org/10.4103/jehp.jehp_91_17

Delgadillo, L. M. (2017). Recognizing Linguistic Cues to Align Financial Coaching Strategies with the Transtheoretical Model of Change. Journal of Extension, 55, Article No. 31.

Fishbein, M., \& Ajzen, I. (1975). Belief, Attitude, Intention and Behaviour: An Introduction to Theory and Research (1st ed.). Boston, MA: Addison-Wesley.

Fornell, C., \& Larcker, D. F. (1981). Evaluating Structural Equation Models with Unobservable Variables and Measurement Error. Journal of Marketing Research, 18, 39-50. https://doi.org/10.1177\%2F002224378101800104

Franca, C. L., Broman, G., Robert, K. H., Basile, G., \& Trygg, L. (2017). An Approach to Business Model Innovation and Design for Strategic Sustainable Development. Journal of Cleaner Production, 140, 155-166. https://doi.org/10.1016/j.jclepro.2016.06.124

Friman, M., Huck, J., \& Olsson, L. E. (2017). Transtheoretical Model of Change during Travel Behavior Interventions: An Integrative Review. International Journal of Environmental Research and Public Health, 14, Article No. 581. https://doi.org/10.3390/ijerph14060581

Gao, L., Wang, S. Y., Li, J., \& Li, H. D. (2017). Application of the Extended Theory of Planned Behavior to Understand Individual's Energy Saving Behavior in Workplaces. Resources, Conservation and Recycling, 127, 107-113. https://doi.org/10.1016/j.resconrec.2017.08.030

Gur, K., Erol, S., Kadioglu, H., Ergun, A., \& Boluktas, R. (2019). The Impact on Adoles- 
cents of a Transtheoretical Model-Based Programme on Fruit and Vegetable Consumption. Public Health Nutrition, 22, 2500-2508.

https://doi.org/10.1017/S136898001900137X

Heinonen, K., \& Strandvik, T. (2015). Customer-Dominant Logic: Foundations and Implications. Journal of Services Marketing, 29, 472-484.

https://doi.org/10.1108/JSM-02-2015-0096

Heinonen, K., Strandvik, T., Mickelsson, K. J., Edvardsson, B., Sundstrom, E., \& Andersson, P. (2010). A Customer-Dominant Logic of Service. Journal of Service Management, 21, 531-548. https://doi.org/10.1108/09564231011066088

Hollebeek, L. D., Srivastava, R. K., \& Chen, T. (2019). S-D Logic-Informed Customer Engagement: Integrative Framework, Revised Fundamental Propositions, and Application to CRM. Journal of the Academy of Marketing Science, 47, 161-185.

https://doi.org/10.1007/s11747-016-0494-5

Hung, W.-T., \& Yuan, S.-T. (2014). On Service Productivity: The Emerging Platforms Perspective. Journal of Service Science and Management, 7, 92-109. https://doi.org/10.4236/jssm.2014.72009

Karnowski, V., Leonhard, L., \& Kumpel, A. S. (2018). Why Users Share the News: A Theory of Reasoned Action-Based Study on the Antecedents of News-Sharing Behavior. Communication Research Reports, 35, 91-100.

https://doi.org/10.1080/08824096.2017.1379984

Lemken, D., Spiller, A., \& von Meyer-Hofer, M. (2017). The Case of Legume-Cereal Crop Mixtures in Modern Agriculture and the Transtheoretical Model of Gradual Adoption. Ecological Economics, 137, 20-28. https://doi.org/10.1016/j.ecolecon.2017.02.021

Lin, X. L., \& Wang, X. Q. (2020). Examining Gender Differences in People's Information-Sharing Decisions on Social Networking Sites. International Journal of Information Management, 50, 45-56. https://doi.org/10.1016/j.ijinfomgt.2019.05.004

Lohmoller, J. -B. (1981). Latent Variable Path Modeling with Partial Least Squares (1st ed.). Heidelberg: Physica-Verlag.

Maglio, P. P., \& Spohrer, J. (2008). Fundamentals of Service Science. Journal of the Academy of Marketing Science, 36, 18-20. https://doi.org/10.1007/s11747-007-0058-9

Marcus, B. H., \& Simkin, L. R. (1994). The Transtheoretical Model: Applications to Exercise Behavior. Medicine and Science in Sports and Exercise, 26, 1400-1404. https://doi.org/10.1249/00005768-199411000-00016

Moreira, P. A. S., Faria, V., Cunha, D., Inman, R. A., \& Rocha, M. (2020). Applying the Transtheoretical Model to Adolescent Academic Performance Using a Person-Centered Approach: A Latent Cluster Analysis. Learning and Individual Differences, 78, Article ID: 101818. https://doi.org/10.1016/j.lindif.2019.101818

Oinas-Kukkonen, H. (2013). A Foundation for the Study of Behavior Change Support Systems. Personal and Ubiquitous Computing, 17, 1223-1235. https://doi.org/10.1007/s00779-012-0591-5

Pine, B. J., \& Gilmore, J. H. (1998). Welcome to the Experience Economy. Harvard Business Review, 76, 97-106.

Prahalad, C. K., \& Ramaswamy, V. (2004). The Future of Competition: Co-Creating Unique Value with Customers (1st ed.). Boston, MA: Harvard Business Press.

Prochaska, J. O., \& Velicer, W. F. (1997). The Transtheoretical Model of Health Behavior Change. American Journal of Health Promotion, 12, 38-48. https://doi.org/10.4278\%2F0890-1171-12.1.38

Prochaska, J. O., Diclemente, C. C., \& Norcross, J. C. (1992). In Search of How People 
Change-Applications to Addictive Behaviors. American Psychologist, 47, 1102-1114. https://doi.apa.org/doi/10.1037/0003-066X.47.9.1102

Quartuch, M. R., Allred, S. B., Markowitz, E., Catanzaro, P., \& Markowski-Lindsay, M. (2021). Applying the Transtheoretical Model of Change to Legacy Planning Decisions. Small-Scale Forestry, 22, 1-22. https://doi.org/10.1007/s11842-021-09476-7

Rollnick, S., Miller, W. R., \& Butler, C. (2008). Motivational Interviewing in Health Care: Helping Patients Change Behavior (1st ed.). New York, NY: Guilford Press.

Stewart-Sicking, J. A., Deal, P. J., \& Fox, J. (2017). The Ways Paradigm: A Transtheoretical Model for Integrating Spirituality into Counseling. Journal of Counseling and Development, 95, 234-241. https://doi.org/10.1002/jcad.12135

Tseng, H. M., Liao, S. F., Wen, Y. P., \& Chuang, Y. J. (2017). Stages of Change Concept of the Transtheoretical Model for Healthy Eating Links Health Literacy and Diabetes Knowledge to Glycemic Control in People with Type 2 Diabetes. Primary Care Diabetes, 11, 29-36. https://doi.org/10.1016/j.pcd.2016.08.005

Tukker, A. (2004). Eight Types of Product-Service System: Eight Ways to Sustainability? Experiences from SusProNet. Business Strategy and the Environment, 13, 246-260. https://doi.org/10.1002/bse.414

Voss, C., Roth, A. V., \& Chase, R. B. (2008). Experience, Service Operations Strategy, and Services as Destinations: Foundations and Exploratory Investigation. Production and Operations Management, 17, 247-266. https://doi.org/10.3401/poms.1080.0030 